\title{
Common and contrasting themes in host cell-targeted effectors from bacterial, fungal, oomycete and nematode plant symbionts described using the Gene Ontology
}

\author{
Trudy Torto-Alalibo' ${ }^{1}$, Candace W Collmer ${ }^{2,3}$, Magdalen Lindeberg3, \\ David Bird ${ }^{4}$, Alan Collmer ${ }^{3}$ and Brett M Tyler*1
}

Address: ${ }^{1}$ Virginia Bioinformatics Institute, Virginia Polytechnic Institute and State University, Blacksburg, VA 24061, USA, ${ }^{2}$ Department of Biological and Chemical Sciences, Wells College, Aurora, NY 13026, USA, ${ }^{3}$ Department of Plant Pathology and Plant-Microbe Biology, Cornell University, Ithaca, NY 14853, USA and ${ }^{4}$ Center for the Biology of Nematode Parasitism, North Carolina State University, Raleigh, NC 27695, USA

Email: Trudy Torto-Alalibo - trudy@vbi.vt.edu; Candace W Collmer - ccollmer@wells.edu; Magdalen Lindeberg - ml16@cornell.edu; David Bird - david_bird@ncsu.edu; Alan Collmer - arc2@cornell.edu; Brett M Tyler* - bmtyler@vt.edu

* Corresponding author

Published: 19 February 2009

BMC Microbiology 2009, 9(SuppI I):S3 doi:10.1 186/I47I-2I80-9-SI-S3

This article is available from: http://www.biomedcentral.com/I47I-2I80/9/SI/S3

(c) 2009 Torto-Alalibo et al; licensee BioMed Central Ltd.

This is an open access article distributed under the terms of the Creative Commons Attribution License (http://creativecommons.org/licenses/by/2.0), which permits unrestricted use, distribution, and reproduction in any medium, provided the original work is properly cited.

\begin{abstract}
A wide diversity of plant-associated symbionts, including microbes, produce proteins that can enter host cells, or are injected into host cells in order to modify the physiology of the host to promote colonization. These molecules, termed effectors, commonly target the host defense signaling pathways in order to suppress the defense response. Others target the gene expression machinery or trigger specific modifications to host morphology or physiology that promote the nutrition and proliferation of the symbiont. When recognized by the host's surveillance machinery, which includes cognate resistance $(R)$ gene products, defense responses are engaged to restrict pathogen proliferation. Effectors from diverse symbionts may be delivered into plant cells via varied mechanisms, including whole organism cellular entry (viruses, some bacteria and fungi), type III and IV secretion (in bacteria), physical injection (nematodes and insects) and protein translocation signal sequences (oomycetes and fungi). This mini-review will summarize both similarities and differences in effectors and effector delivery systems found in diverse plant-associated symbionts as well as how these are described with Plant-Associated Microbe Gene Ontology (PAMGO) terms.
\end{abstract}

\section{Effectors from diverse plant-associated symbionts}

Diverse organisms live in intimate association with plants, with the outcome of these associations dependent upon a complex interplay of gene products. Among the most significant of these are the effector proteins, defined as molecules deployed by symbiotic organisms that manipulate host cell structure and function, and thereby facilitate symbiont success [1]. In some cases, through the action of the host surveillance machinery, effectors trigger defense responses; in that context, effectors have historically been called avirulence factors or elicitors. In fact, the detection of effectors by the products of host resistance (R) genes has been central to the identification of effectors in diverse symbionts (reviewed in $[2,3]$ ). This particular review will focus on properties of effector proteins that enter the host cytoplasm and the role that Gene Ontology (GO) can play in highlighting similarities and differences exhibited by effectors deployed by plant pathogens from diverse biological kingdoms.

It is important to note that while this review focuses on organisms living in a pathogenic relationship with the host plant, there are many associations that cannot readily 
be identified as beneficial or antagonistic to the host because the outcome depends on the context in which it occurs. For example, while some rhizobacteria are pathogenic, their colonization of plant roots can also play a beneficial role by priming plant defense responses, thus making the plant more resistant to infection by unrelated pathogens. As a result, the term "symbiont" is used by the $\mathrm{GO}$ and in this review to describe organisms living in intimate association with a larger host organism, irrespective of whether the association may be beneficial or antagonistic. The Gene Ontology Consortium (GOC) strongly discourages the use of the word symbiosis as a synonym for mutualism. Symbionts may be microbes (for example bacteria, fungi or oomycetes) or they may be more complex multicellular organisms such as nematodes, insects or parasitic plants.

Many gram-negative bacterial symbionts, including mutualists of the genus Rhizobium and pseudomonad and xanthomonad pathogens, utilize a molecular needle created by the type III or type IV secretion systems to deliver effectors into the host cell (reviewed in [4-6]). Most progress in effector characterization has been made with the gramnegative bacterial pathogens. The sequencing of gramnegative bacterial genomes has further advanced the discovery of effectors by enabling bioinformatic identification of new candidate effectors [7,8]. Bioinformatic analysis of genome sequences has also greatly advanced the identification of the effectors produced by obligate symbionts such as gram-positive phytoplasmas [9].

Oomycete and fungal pathogens represent different kingdoms of life but share similar strategies in colonizing their hosts, presumably as a result of convergent evolution [10]. Biochemical and genetic approaches have identified effectors from both taxa (reviewed in [1,11-15]). Given the predicted role of the haustorium, a differentiated feeding structure produced by both fungi and oomycetes $[16,17]$, as a site of effector release, identification of haustorially expressed secreted proteins (HESPs) has proven to be a valuable source of candidate effectors $[18,19]$. Genome sequences of fungal and oomycete pathogens have dramatically accelerated the discovery of effectors via bioinformatic analyses of predicted secretomes [20-25]. In particular, the discovery of the protein transduction motif RXLR-dEER [25-27] enabled the identification of hundreds of effector candidates in oomycete genomes $[21,24,28]$.

Nematodes comprise a large phylum of animals that include free-living species as well as plant and animal parasites. Most plant pathogenic nematodes are obligate parasites and obtain nutrients from the cytoplasm of living root cells. The sedentary endoparasites of the family Heteroderidae, which include members of the genera Heterod- era (cyst nematode) and Meloidogyne (root knot nematode) cause the most economic damage worldwide. Infection by these pathogens is characterized by the release of esophageal gland secretions via a hollow protrusible stylet [29]. During nematode migration, cell wall degrading enzymes $[30,31]$ are released into the apoplast in amounts sufficiently copious to be visible under the light microscope [32]. Upon becoming sedentary, other proteins, including plant peptide hormone mimics [33], are delivered to those cells destined to become the feeding sites. This occurs via fusion of neighboring cells (for cyst nematodes) or via repeated nuclear division (in the case of root knot nematodes). It is presumed that nematode proteins, sometimes called parasitism proteins, are introduced both onto the membrane surface of the targeted plant cells, and also directly into the cytoplasm.

Effectors from diverse microbes have little in common at the sequence level, but as a result of convergent evolution, may implement common strategies in defeating host defenses. Therefore, in order to carry out functional comparisons of diverse effectors, an approach is required that does not depend on sequence similarities. The GO provides such an approach. Established in 1998, the GO provides a uniform language to describe attributes of gene products from all organisms in the context of their molecular function, biological process, and cellular location [34,35]. The Plant-Associated Microbe Gene Ontology (PAMGO) consortium [36] was established in 2004 to develop GO terms to describe common biological processes utilized by symbionts (particularly microbes) in their interactions with hosts. The current count of terms created via the PAMGO effort is over 700. To create wellannotated reference genomes that provide high quality examples of the usage of the new terms, the consortium has been using the terms to annotate the genomes of the bacteria Pseudomonas syringae pv tomato DC3000, Dickeya dadantii (Erwinia chrysanthemii) 3937, and Agrobacterium tumefaciens; the fungus Magnaporthe oryzae (M. grisea); and the oomycete Phytophthora sojae.

This review focuses on the effectors and effector delivery systems of diverse plant-associated microbes and nematodes with an emphasis on pathogens. Similarities and differences in pathogen-host associations with respect to the role of effectors are described in the context of GO terms that best describe them. This is by no means a comprehensive coverage of the subject due to space limitations, but rather is intended to illustrate the value of using the GO for comparative genome analyses of diverse symbionts.

\section{How are effectors introduced into host cells?}

Critical to effector function is their successful delivery to their site of action in the host cell. For the pathogens dis- 

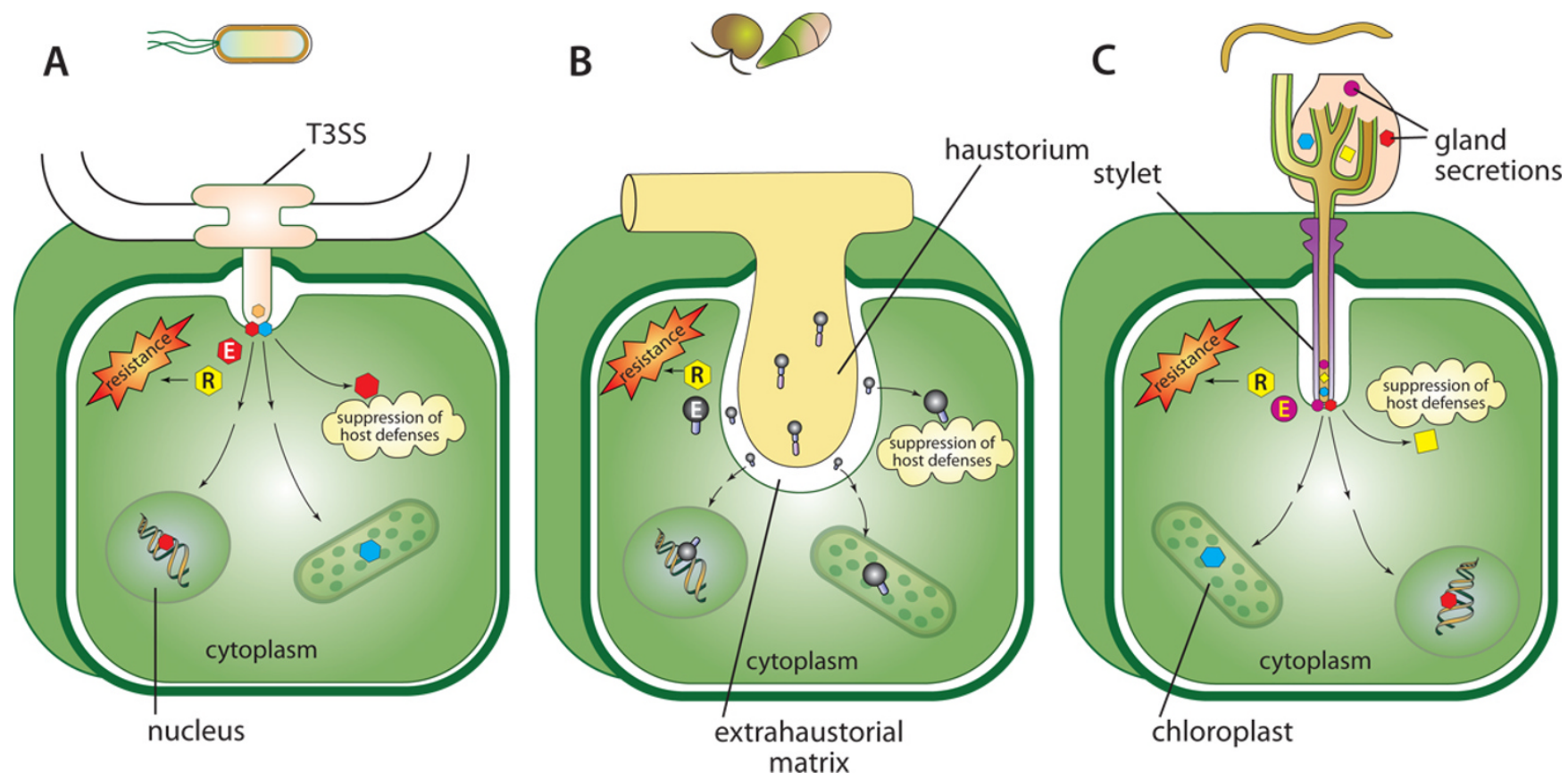

Figure I

Effector delivery structures of Gram-negative bacterium, oomycete, fungus, and nematode in plant cell. (A) Type III secretion system in Gram-negative bacterium injects effectors into the host cell. (B) The haustorium in biotrophic and hemibiotrophic filamentous pathogens is believed to be the site of effector release into the host cell. (C) Gland secretions, which include effectors, are injected into the plant cell via the stylet of the nematode. Effectors (E) thus delivered, can either suppress host defenses and/or trigger host cell defenses, which include programmed cell death (PCD) upon recognition by resistance $(R)$ proteins. Recognition of effectors by $R$ proteins may occur directly (observed with some fungal effectors) or indirectly as a result of interaction of the effectors with other host protein(s) (observed with a number of bacterial effectors). Potential subcellular locations of effectors such as the nucleus and chloroplasts are also shown.

cussed here, this process involves passage across the plant cell wall and the plasma membrane. The injectisomes of bacterial type III and type IV secretion systems (T3SS and T4SS) respectively; (reviewed in [6,37-39]) are analogous to the stylets of plant parasitic nematodes. Also known as the Hrp pilus, the T3SS injectisome spans both the bacterial envelope and the plant cell wall, forming a channel between the bacterial cytoplasm and the host plasma cell membrane. Secreted proteins delivered by the injectisome then form a pore through the membrane that enables translocation of effector proteins into the host cell (Figure 1a) [5]. The stylet in nematodes executes an analogous function, in that it mechanically pierces the host cell wall but not the membrane and injects gland secretions, including effectors, into the host cell cytoplasm via an orifice at the tip of the stylet (Figure 1c) $[31,40]$.

In the case of many biotrophic and hemibiotrophic fungi and oomycetes, penetration of the host cell wall is accomplished via a hypha that differentiates into a specialized feeding structure called a haustorium (in the case of pathogenic fungi and oomycetes) or an arbuscle (in the case of mutualistic arbuscular mycorrhizal fungi). The hausto- rium becomes surrounded by a specialized interface consisting of the plasma membranes of the pathogen and host separated by a modified pathogen cell wall (Figure 1b) $[41,42]$. The haustorial interface is speculated to be the site of nutrient acquisition as well as the site of effector release from the pathogen into the plant tissue [16], though the mechanism of subsequent effector transfer across the plasma membrane remains uncharacterized.

The GO provides terms to describe gene products involved in the formation of these effector delivery structures, the gene products aiding in the delivery of effectors, and the gene products (effectors) that are delivered through these structures. The PAMGO Consortium has contributed many of these terms. $[10,43,44]$. We use the T3SS as an illustration. Gene products encoding the structural components of the T3SS injectisome may be annotated with the cellular component term "GO:0030257 type III protein secretion system complex". Furthermore, gene products that are involved in the secretion of effectors into the host cell, including helper proteins such as chaperones and harpins may be annotated with the process term, "GO:0030254 protein secretion by the type III 
secretion system". The term "GO:0052049 interaction with host via protein secreted by type III secretion system" may be used to annotate all gene products that are secreted via the T3SS and that interact with the host. These will include harpins and effectors delivered via the T3SS. Additionally the effectors may be annotated with the GO cellular component term "GO:0043657 host cell" to indicate the site of interaction with the host. A direct parent term of "GO:0052049 interaction with host via protein secreted by type III secretion system" is "GO:0052048 interaction with host via secreted substance" which is in turn a child term of "GO:0051701 interaction with host". As basis for comparison, a new sibling term to GO:0052049, "interaction with host via protein secreted by the stylet" has been created for annotation of nematode effector proteins.

The exact mechanism by which oomycete and fungal effectors enter plant cells is not clear, though the haustorial interface is speculated to be the site of entry. Recent studies of two oomycete effectors, Avr1b from P. sojae and Avr3a from $P$. infestans have identified the motif RXLRdEER, present in the $\mathrm{N}$-terminus of both proteins, as being necessary and sufficient to deliver proteins into the plant cell $[25,26]$. Although RXLR-dEER-bearing proteins could cross the plasma cell membrane autonomously, some evidence suggests that entry may be more efficient at the haustorium, where the plant cell wall was penetrated [26], emphasizing the analogy of the haustorial hypha with the T3SS injectisome and the nematode stylet.

Subsequent to characterization of Avr1b and Avr3a, a super-family of 385 RXLR dEER proteins in the P. sojae genome and 370 in the $P$. ramorum genome was identified using bioinformatic approaches such as recursive BLAST and HMM searches [21]. The existence of this predictive motif among oomycete effectors with varying levels of experimental characterization can be used to highlight the importance of evidence codes in GO annotation. Given the experimental evidence, the Phytophthora Avr1b and Avr3a gene products can be annotated with "GO:0052048 interaction with host via secreted substance" with an experimental evidence code. Once a specific structure or mechanism is identified through which the effectors are delivered, a more specific child term will be created and applied. Given the presence of the RXLR-dEER motif in the bioinformatically characterized proteins, it is appropriate to infer that like Avr1b, these proteins are also targeted to the host cell and can be annotated to "GO:0052048 interaction with host via secreted substance". However, in these cases the annotation would be accompanied by the evidence code "Inferred from Sequence Model" (ISM) with the Avr1b protein accession documented as the experimentally characterized effector.

\section{Where do they lay camp when in the host?}

Prokaryote and eukaryotic pathogens alike secrete effector proteins into the host apoplast as well as into host cells where they may localize to the cytoplasm and subcellular compartments, including the mitochondrion, nucleus and the chloroplast. Specific terms were developed by the PAMGO consortium under the cellular component ontology to describe gene products from one organism (symbiont) that act in the extracellular and cellular regions of another organism (host) cell. These terms are different from terms developed to describe gene products from an organism acting in cellular locations within the same organism. Gene products from one organism acting in regions of another organism are described with "GO:0043657 host cell" and its child terms. The term host cell has a "part-of" relationship with the parent term "GO:0018995 host" which in turn is a child term of "GO:0043245 extraorganismal space". In contrast, gene products from one organism acting in regions of that same organism are captured under "GO:0044464 cell part" and its child terms. "Cell part" has a part of relationship with "GO:0005623 cell" which is a direct child of the root "GO:0005575 cellular component". We illustrate the use of these terms with gene products from diverse organisms. For example, "GO:0043655 extracellular space of host" can be used to describe microbial gene products secreted into the apoplast of plant cells while "GO:0005615 extracellular space" is used to describe microbial gene products shown to be located outside of the microbe's plasma membrane. Apoplastic effectors are secreted into the plant extracellular space where they interact with extracellular targets and surface proteins. For example, plant cell wall-degrading enzymes secreted by bacterial, fungal, oomycete and nematode pathogens could be annotated with "GO:0043245 extraorganismal space".

Many effectors from bacterial, fungal, oomycete and nematode pathogens can enter the cytoplasm of host cells, and could be annotated with the term "GO:0030430 host cell cytoplasm" unless a more specific location was identified. In some cases, the evidence for host cytoplasmic location is indirect, for example, some effector proteins are recognized by intracellular plant disease resistance gene products [45]. In other cases the evidence for cytoplasmic localization is directly supported by experimental evidence showing physical interactions between effectors and resistance gene products or other proteins in the plant cytoplasm. Examples include the Magnaporthe oryzae effector AvrPita which interacts with the rice resistance gene product Pita [46]. In other cases, effector proteins have been identified in the plant cell cytoplasm cytologically: by antibody staining or via a fluorescent tag. These include, for example, the bacteria effectors, HopAB2 [47] 
and HopU1 [48]; and the oomycete effectors Avr1b [26] and Avr3a [49].

Some intracellular effectors have also been located in specific host organelles, including the nucleus and chloroplast, and thus can be annotated with "GO:0042025 host cell nucleus" or "GO:0033652 host cell chloroplast" respectively. Examples of nucleus-located effectors include AvrBs3 and other members of the AvrBs3 family from Xanthomonas bacteria [50], the rust transferred protein 1 (Uf-RTP1p) from the fungus Uromyces fabae [51], four putative effectors from the oomycete Phytophthora infestans (Nuk6, Nuk7, Nuk10, Nuk12) [52], and two nematode parasitism proteins [53]. An example of a chloroplast-located effector is HopI1 [54].

\section{What effectors do in the host}

Plants have evolved mechanisms to passively withstand or actively resist invading microbes by deploying defense responses. Defense responses may be triggered by plant recognition of commonly occurring pathogen molecules called pathogen-associated molecular patterns (PAMPS) such as bacterial flagellin (PAMP triggered immunity; PTI) or by direct or indirect recognition of pathogen effectors (effector triggered immunity; ETI) (reviewed in $[55,56]$ ).

An important process associated with defense against biotrophic and hemibiotrophic pathogens is programmed cell death (PCD). Many pathogen effectors have been demonstrated to suppress PCD. Among these are HopAB2 (AvrPtoB) from P. syringae [57] and oomycete effectors such as Phytophthora sojae Avr1b [58], which have been shown to inhibit defense-like PCD triggered in plants by other effectors or by the pro-apoptotic mammalian BAX protein. Similarly, the P. infestans effector AVR $3 \mathrm{a}^{\mathrm{KI}}$ can suppress PCD triggered by the PAMP, INF1 in Nicotiana benthamiana [59]. These effectors can be annotated with "GO:0034054 negative regulation by symbiont of host defense-related programmed cell death". In contrast to biotrophs and hemibiotrophs, necrotrophs induce PCD in order to colonize their host [60]. For example, the Nep1-like protein $\mathrm{NPP}_{\mathrm{Ps}}$ (previously called PsojNIP) from the hemibiotrophic oomycete pathogen $P$. sojae causes necrosis in soybean. Its expression during the transition from biotrophy to necrotrophy [61] suggests its effector role is to manipulate PCD to the advantage of the pathogen. This role can be described jointly with the two GO terms "GO:0052042 positive regulation by symbiont of host programmed cell death" and "GO:0009405 pathogenesis".

The specific processes that contribute to ETI and PTI are complex and many of their details remain a mystery. However, ongoing characterization of individual effectors has revealed new insights into the various defense mecha- nisms deployed by the host and subject to interference by the symbiont. One method of defense suppression involves inactivation, modification, or suppression of host defense proteins. For example, XopD and AvrXv4 from Xanthomonas campestris are cysteine proteases that have been predicted to remove SUMO (small ubiquitinlike modifier) modifications from components of the defense pathways (reviewed in [62]). The P. syringae effectors AvrRpt2 and HopAR1 (AvrPphB) also function as cysteine proteases $[63,64]$ while the fungal effector AvrPita from Magnaporthe oryzae is a zinc metalloprotease [65]. These effectors can be annotated with the term "GO:0052014 catabolism by symbiont of host protein".

Inhibition of host hydrolytic enzymes is another mechanism by which effectors interfere with the functions of host defense proteins. For example, the extracellular fungal effectors Avr2 and Avr4 from Cladosporium fulvum can inhibit the tomato extracellular protease, Rcr3 [66], and host chitinases [67] respectively. In oomycetes, the glucanase inhibitor protein (GIP1) secreted by P. sojae inhibits endoglucanse ability of the plant host [68] and apoplastic effectors EPI1 and EPI10 from P. infestans inhibit the P69B subtilase of tomato $[69,70]$. These host hydrolase inhibitors can be described with "GO:0052053 negative regulation by symbiont of host enzyme activity".

Hallmarks of PTI include not only deployment of defense proteins but also deposition of callose in the host cell wall. Several bacterial and oomycete effectors have been shown to suppress callose deposition in planta, including AvrE [71], AvrPto [72], HopM1 [71] from Pseudomonas syringae, DspA/E [73] from Erwinia amylovora and ATR1 from the oomycete Hyaloperonospora arabidopsidis [74]. The appropriate GO term to describe this virulence function is "GO:0052087 negative regulation by symbiont of defense-related host callose deposition".

The various defense responses involved in a successful immune response are dependent on an array of signaling pathways that link pathogen detection to host response. These defense signals include the hormone ethylene, jasmonic acid, and salicylic acid with each representing a target for interference by symbiont effectors. For example, bacterial effectors AvrB and AvRpt2 [75] have been shown to trigger the expression of the ethylene-responsive transcription factor (RAP2.6) in Arabidopsis via jasmonic acid signaling thereby repressing salicylic acid (SA) mediated PAMP-triggered defense responses against biotrophic pathogens. The phytotoxin, coronatine from $P$. syringae mimics jasmonic acid also leading to repression of SA signaling [76]. In other cases, hormone signaling is disrupted for the purpose of modifying host morphology. The Meloidogyne javanica chorismate mutase 1 (MjCM-1) [77], is secreted into plant cells where it reduces the synthesis of 
auxins, flavanoids, SA and phytoalexins. A general term for describing effectors that modulate hormone signaling is "GO:0052027 modulation by symbiont of host signal transduction pathway", while a more specific term to describe interference with the host salicylic pathway is "GO:0052003 negative regulation by symbiont of defense-related host salicylic acid-mediated signal transduction pathway".

Though a direct role in virulence beyond defense suppression remains elusive for most microbial effectors, esophageal gland secretions translocated into host cells via the nematode stylet play major roles in modification of host cells for feeding and pathogenesis [78]. In particular, the Heterodera glycines effector HG-SYV46 acts as a functional analog of the plant cellular proliferation regulators that include CLAVATA3 [33]. Effectors such as HG-SYV46 with a demonstrated role in inducing the modification of these plant cells can be annotated with the term "GO:0044005 induction by symbiont in host of tumor, nodule, or growth" which is a child of "GO:0044003 modification by symbiont of host morphology or physiology". Another annotation could be made using "GO:0052096 formation by symbiont of syncytium involving giant cell for nutrient acquisition from host", a child term of "GO:0052093 formation of specialized structure for nutrient acquisition from host".

Though effectors have proven highly effective in suppression of plant defense, the fact remains that in the ongoing arms race between host and symbiont, hosts have evolved successful means of detecting many of the known effectors, most notably through deployment of resistance (R) proteins. Effectors recognized directly or indirectly by $\mathrm{R}$ proteins have been termed avirulence proteins and include (among many others) the bacterial effectors AvrPto, AvrRpt2, and AvrRpm1 (reviewed in [79]), the oomycete effectors Avr1b, Avr4, ATR13 and ATR1 ${ }^{\text {Nd }}$ (reviewed in [15]), the fungal effectors Avr-Pita, AvrL567, AvrM, AvrP123 and AvrP4 (reviewed in $[12,13]$ ) and the nematode effectors map1 [80] and Cg-1 [81]. The induction of defense responses by these effectors can be annotated with "GO:0052509 positive regulation by symbiont of host defense response" or if a resistance gene has been identified, "GO:0052527 positive regulation by symbiont of host resistance gene-dependent defense response". If host defense-related programmed cell death is involved, annotation can be made to "GO:0034055 positive regulation by symbiont of host defense-related programmed cell death". Note that these terms differ from "GO:0052042 positive regulation by symbiont of host programmed cell death" which is used to annotate toxins produced by some necrotrophs. It could be argued that positive regulation by the symbiont of the host defense response is deleterious to the symbiont, and hence is not a natural symbiont process. However, what is deleterious to the symbiont can be highly dependent on the context (just as "pathogenicity" is highly context-dependent) with regard to the bio/necro-trophic nature of the interaction. Thus the GO does not attempt to describe the outcome of symbiont processes. An ongoing initiative in the GO in the context of host-symbiont interactions is to create a mechanism to record information about the actual host protein (e.g., an $R$ gene product) that mediates the response to a particular effector. Currently there is no way to record interacting proteins in the GO unless the experiment involves direct physical interactions where the "Inferred from Physical Interaction" (IPI) evidence code (see [82] for more information on GO evidence codes) can be used. However, at the current time all the annotations described above where effectors are secreted and act in the host organism would be accompanied by the taxon ids of both the microbe and the plant host.

Overall, modifications made to the host, either by triggering host defenses and/or suppressing host defenses can be described under the broad term "GO:0044003 modification by symbiont of host morphology or physiology". The child terms under GO:0044003 can be used to describe specific effector modifications in the host.

\section{Conclusion}

The value of GO annotations in efficiently summarizing information about gene products from the literature in a standardized way cannot be over-emphasized. Careful GO annotations enable the systematic synthesis of both accumulating sequences from genome projects and advances in studies on effector biology, which provides a wealth of data that is easily accessible to the scientific community. The GO terms developed by the PAMGO consortium greatly improve the resources for annotation of diverse symbiont genomes, particularly for gene products such as effectors that are directly involved in the interaction with the host. Such annotations can be used to aid interpretation of genome sequence comparisons and of microarray and proteomics data. Increased community involvement in GO annotation of more symbiont genomes, along with the development of additional GO terms, will provide valuable resources for more comprehensive cross-kingdom effector analyses, which ultimately will lead to a better understanding of mechanisms underlying symbiont interactions with hosts.

\section{Competing interests}

The authors declare that they have no competing interests.

\section{Acknowledgements}

The authors would like to thank the editors at The Gene Ontology Consortium, in particular Jane Lomax and Amelia Ireland and the members of the PAMGO Consortium, for their collaboration in developing many PAMGO terms. We thank June Mullins for the illustration. This work was 
supported by the National Research Initiative of the USDA Cooperative State Research, Education and Extension Service, grant number 2005$35600-16370$ and by the U.S. National Science Foundation, grant number EF-0523736. In addition, CWC received funding in initial stages of the project from two NSF ROA awards (NSF award \# DBI-0077622) and from the Kauffman Foundation.

This article has been published as part of BMC Microbiology Volume 9 Supplement I, 2009: The PAMGO Consortium: Unifying Themes In MicrobeHost Associations Identified Through The Gene Ontology. The full contents of the supplement are available online at http://www.biomedcen tral.com/ $|47|-2 \mid 80 / 9$ ? issue $=$ SI.

\section{References}

I. Kamoun S: A catalogue of the effector secretome of plant pathogenic oomycetes. Annu Rev Phytopathol 2006, 44:4I-60.

2. Gurlebeck D, Thieme F, Bonas U: Type III effector proteins from the plant pathogen Xanthomonas and their role in the interaction with host plant. Journal of Plant Physiology 2006, 163:233-255.

3. Shan W, Cao M, Leung D, Tyler BM: The Avr Ib locus of Phytophthora sojae encodes an elicitor and a regulator required for avirulence on soybean plants carrying resistance gene $R p s / b$. Mol Plant Microbe Interact 2004, 17(4):394-403.

4. Fauvart M, Michiels J: Rhizobial secreted proteins as determinants of host specificity in the rhizobium-legume symbiosis. FEMS Microbiol Lett 2008, 285(I): I-9.

5. Galan JE, Wolf-Watz H: Protein delivery into eukaryotic cells by type III secretion machines. Nature 2006, 444(7 I I 9):567-573.

6. Grant SR, Fisher EJ, Chang JH, Mole BM, Dangl JL: Subterfuge and manipulation: Type III effector proteins of phytopathogenic bacteria. Annual Review of Microbiology 2006, 60:425-449.

7. Lindeberg M, Cartinhour S, Myers CR, Schechter LM, Schneider DJ, Collmer A: Closing the circle on the discovery of genes encoding Hrp regulon members and type III secretion system effectors in the genomes of three model Pseudomonas syringae strains. Mol Plant Microbe Interact 2006, I 9(II): I I5I-I I 58.

8. Vinatzer BA, Jelenska J, Greenberg JT: Bioinformatics correctly identifies many type III secretion substrates in the plant pathogen Pseudomonas syringae and the biocontrol isolate $P$. fluorescens SBW25. Mol Plant Microbe Interact 2005, 18(8):877-888.

9. Hogenhout SA, Oshima K, Ammar el D, Kakizawa S, Kingdom HN, Namba S: Phytoplasmas: bacteria that manipulate plants and insects. Mol Plant Pathol 2008, 9(4):403-423.

10. Meng S, Torto-Alalibo T, Chibucos MC, Tyler BM, Dean RA: Common processes in pathogenesis by fungal and oomycete plant pathogens, described with Gene Ontology terms. BMC Microbiology 2009, 9(SuppI I):S7.

II. Dodds PN, Catanzariti AM, Lawrence GJ, Ellis JG: Avirulence proteins of rust fungi: penetrating the host-haustorium barrier. Australian Journal of Agricultural Research 2007, 58:5 I2-5I7.

12. Ebbole DJ: Magnaporthe as a model for understanding hostpathogen interactions. Annu Rev Phytopathol 2007, 45:437-456.

13. Ellis JG, Dodds PN, Lawrence G]: The role of secreted proteins in diseases of plants caused by rust, powdery mildew and smut fungi. Curr Opin Microbiol 2007, I 0(4):326-33I.

14. Tyler BM: Molecular basis of recognition between Phytophthora pathogens and their hosts. Annu Rev Phytopathol 2002, 40:137-167.

15. Tyler BM: Entering and breaking: virulence effector proteins of oomycete plant pathogens. Cell Microbiol 2009, I I(I): 13-20.

16. Chibucos MC, Tyler BM: Common themes in nutrient acquisition by plant symbiotic microbes, described by the Gene Ontology. BMC Microbiology 2009, 9(SuppI I):S6.

17. Mendgen $\mathrm{K}$, Hahn M: Plant infection and the establishment of fungal biotrophy. Trends Plant Sci 2002, 7(8):352-356.

18. Catanzariti AM, Dodds PN, Lawrence G], Ayliffe MA, Ellis JG: Haustorially expressed secreted proteins from flax rust are highly enriched for avirulence elicitors. Plant Cell 2006, I 8(I):243-256.

19. Hahn M, Mendgen K: Characterization of in planta-induced rust genes isolated from a haustorium-specific cDNA library. Mol Plant Microbe Interact 1997, 10(4):427-437.
20. Dean RA, Talbot NJ, Ebbole DJ, Farman ML, Mitchell TK, Orbach MJ, Thon M, Kulkarni R, Xu JR, Pan H, et al:: The genome sequence of the rice blast fungus Magnaporthe grisea. Nature 2005, 434(7036):980-986.

21. Jiang RH, Tripathy S, Govers F, Tyler BM: RXLR effector reservoir in two Phytophthora species is dominated by a single rapidly evolving superfamily with more than $\mathbf{7 0 0}$ members. Proc Natl Acad Sci USA 2008, 105( 1 2):4874-4879.

22. Kamper J, Kahmann R, Bolker M, Ma LJ, Brefort T, Saville BJ, Banuett F, Kronstad JW, Gold SE, Muller O, et al.: Insights from the genome of the biotrophic fungal plant pathogen Ustilago maydis. Nature 2006, 444(7 II 5):97-101.

23. Mueller O, Kahmann R, Aguilar G, Trejo-Aguilar B, Wu A, de Vries RP: The secretome of the maize pathogen Ustilago maydis. Fungal Genet Biol 2008, 45(Suppl I):S63-70.

24. Tyler BM, Tripathy S, Zhang X, Dehal P, jiang RH, Aerts A, Arredondo FD, Baxter L, Bensasson D, Beynon JL, et al.: Phytophthora genome sequences uncover evolutionary origins and mechanisms of pathogenesis. Science 2006, 3 I3(579 I): $|26|-1266$.

25. Whisson SC, Boevink PC, Moleleki L, Avrova AO, Morales JG, Gilroy EM, Armstrong MR, Grouffaud S, van West P, Chapman S, et al.: A translocation signal for delivery of oomycete effector proteins into host plant cells. Nature 2007, 450(7|66): I I5- I I8.

26. Dou D, Kale SD, Wang X, jiang RH, Bruce NA, Arredondo FD, Zhang X, Tyler BM: RXLR-mediated entry of Phytophthora sojae effector Avr Ib into soybean cells does not require pathogenencoded machinery. Plant Cell 2008, 20:1930-1947.

27. Rehmany AP, Gordon A, Rose LE, Allen RL, Armstrong MR, Whisson SC, Kamoun S, Tyler BM, Birch PR, Beynon JL: Differential recognition of highly divergent downy mildew avirulence gene alleles by RPP I resistance genes from two Arabidopsis lines. Plant Cell 2005, I 7(6): 1839-1850.

28. Win J, Kanneganti TD, Torto-Alalibo T, Kamoun S: Computational and comparative analyses of I 50 full-length $\mathrm{CDNA}$ sequences from the oomycete plant pathogen Phytophthora infestans. Fungal Genet Biol 2006, 43(I):20-33.

29. Linford MB, Oliveira JM: The feeding of hollow-spear nematodes on other nematodes. Science 1937, 85(2203):295-297.

30. Smant G, Stokkermans JP, Yan Y, de Boer JM, Baum TJ, Wang X, Hussey RS, Gommers FJ, Henrissat B, Davis EL, et al.: Endogenous cellulases in animals: isolation of beta-I, 4-endoglucanase genes from two species of plant-parasitic cyst nematodes. Proc Nat Acad Sci USA I998, 95(9):4906-49| I.

31. Vanholme B, De Meutter J, Tytgat T, Van Montagu M, Coomans A, Gheysen G: Secretions of plant-parasitic nematodes: a molecular update. Gene 2004, 332:13-27.

32. Wyss U, Grundler FMW, Münch A: The parasitic behaviour of 2nd-stage juveniles of Meloidogyne incognita in roots of Arabidopsis thaliana. Nematologica 1992, 38:98-III

33. Wang X, Mitchum MG, Gao B, Li C, Diab H, Baum TJ, Hussey RS, Davis EL: A parasitism gene from a plant-parasitic nematode with function similar to CLAVATA3/ESR (CLE) of Arabidopsis thaliana. Molecular Plant Pathology 2005, 6(2):|87-19|.

34. An introduction to the Gene Ontology [http://www.geneontol ogy.org/GO.doc.shtml]

35. Ashburner M, Ball CA, Blake JA, Botstein D, Butler H, Cherry HM, Davis AP, Dolinski K, Dwight SS, Eppig JT, et al:: Gene Ontology: tool for the unification of biology. Nature Genetics 2000 , 25(I):25-29.

36. Plant-Associated Microbe Gene Ontology [http://
] pamgo.vbi.vt.edu/]

37. Alfano JR, Collmer A: Type III secretion system effector proteins: Double agents in bacterial disease and plant defense. Annual Review of Phytopathology 2004, 42:385-4I4.

38. Block A, Li G, Fu ZQ, Alfano JR: Phytopathogen type III effector weaponry and their plant targets. Curr Opin Plant Biol 2008, I I (4):396-403.

39. Tseng T-T, Tyler BM, Setubal JC: Protein secretion systems in bacterial-host associations, and their description in the Gene Ontology. BMC Microbiology 2009, 9(SuppI I):S2.

40. Lilley CJ, Atkinson HJ, Urwin PE: Molecular aspects of cyst nematodes. Mol Plant Pathol 2005, 6:577-588.

4I. Hahn M, Mendgen K: Signal and nutrient exchange at biotrophic plant fungus interfaces. Current Opinion in Plant Biology 200I, 4:322-327. 
42. Hardham AR: Cell biology of plant-oomycete interactions. Cellular Microbiology 2007, 9(I):3I-39.

43. Lindeberg M, Biehl BS, Glasner JD, Perna NT, Collmer A, Collmer $\mathrm{CW}$ : Gene Ontology annotation highlights shared and divergent pathogenic strategies of type III effector proteins deployed by the plant pathogen Pseudomonas syringae pv tomato DC3000 and animal pathogenic Escherichia coli strains. BMC Microbiology 2009, 9(SuppI I):S4.

44. Torto-Alalibo T, Collmer CW, Gwinn-Giglio M: The Plant-Associated Microbe Gene Ontology (PAMGO) Consortium: Community development of new Gene Ontology terms describing biological processes involved in microbe-host interactions. BMC Microbiology 2009, 9(SuppI I):SI.

45. Dangl JL, Jones JD: Plant pathogens and integrated defence responses to infection. Nature 200I, 4 I I (6839):826-833.

46. Jia Y, McAdams SA, Bryan GT, Hershey HP, Valent B: Direct interaction of resistance gene and avirulence gene products confers rice blast resistance. Embo J 2000, 19(15):4004-40I4.

47. de Vries JS, Andriotis VM, Wu AJ, Rathjen JP: Tomato Pto encodes a functional $\mathrm{N}$-myristoylation motif that is required for signal transduction in Nicotiana benthamiana. Plant J 2006, 45(I):3I-45

48. Fu ZQ, Guo M, Jeong BR, Tian F, Elthon TE, Cerny RL, Staiger D, Alfano JR: A type III effector ADP-ribosylates RNA-binding proteins and quells plant immunity. Nature 2007, 447(7| 42):284-288.

49. Armstrong MR, Whisson SC, Pritchard L, Bos JI, Venter E, Avrova AO, Rehmany AP, Bohme U, Brooks K, Cherevach I, et al: An ancestral oomycete locus contains late blight avirulence gene Avr3a, encoding a protein that is recognized in the host cytoplasm. Proc Natl Acad Sci USA 2005, 102(2I):7766-777I.

50. Lahaye T, Bonas U: Molecular secrets of bacterial type III effector proteins. Trends Plant Sci 200I, 6(1 0):479-485.

5I. Kemen E, Kemen AC, Rafiqi M, Hempel U, Mendgen K, Hahn M, Voegele RT: Identification of a protein from rust fungi transferred from haustoria into infected plant cells. Mol Plant Microbe Interact 2005, I 8( I I): I I30-I I39.

52. Kanneganti TD, Bai X, Tsai CW, Win J, Meulia T, Goodin M, Kamoun S, Hogenhout SA: A functional genetic assay for nuclear trafficking in plants. Plant J 2007, 50(I): I49-158.

53. Elling AA, Davis EL, Hussey RS, Baum TJ: Active uptake of cyst nematode parasitism proteins into the plant cell nucleus. Int J Parasitol 2007, 37(I I): I269-1279.

54. Jelenska J, Yao N, Vinatzer BA, Wright CM, Brodsky JL, Greenberg JT: A J domain virulence effector of Pseudomonas syringae remodels host chloroplasts and suppresses defenses. Curr Biol 2007, I 7(6):499-508.

55. Bent AF, Mackey D: Elicitors, effectors, and $\mathbf{R}$ genes: the new paradigm and a lifetime supply of questions. Annu Rev Phytopathol 2007, 45:399-436.

56. Jones JD, Dangl JL: The plant immune system. Nature 2006, 444(7I I 7):323-329.

57. Abramovitch RB, Kim YJ, Chen S, Dickman MB, Martin GB: Pseudomonas type III effector AvrPtoB induces plant disease susceptibility by inhibition of host programmed cell death. Embo J 2003, 22(I):60-69.

58. Dou D, Kale SD, Wang X, Chen Y, Wang Q, Jiang RH, Arredondo FD, Anderson RG, Thakur PB, McDowell JM, et al:: Conserved C-terminal motifs required for avirulence and suppression of cell death by Phytophthora sojae effector Avrlb. Plant Cell 2008, 20(4): III $18-1 \mid 33$.

59. Bos JI, Kanneganti TD, Young C, Cakir C, Huitema E, Win J, Armstrong MR, Birch PR, Kamoun S: The C-terminal half of Phytophthora infestans RXLR effector AVR3a is sufficient to trigger R3a-mediated hypersensitivity and suppress INFI-induced cell death in Nicotiana benthamiana. Plant J 2006, 48(2): | $65-176$.

60. Glazebrook J: Contrasting mechanisms of defense against biotrophic and necrotrophic pathogens. Annu Rev Phytopathol 2005, 43:205-227.

6I. Qutob D, Kamoun S, Gijzen M: Expression of a Phytophthora sojae necrosis-inducing protein occurs during transition from biotrophy to necrotrophy. Plant J 2002, 32(3):36I-373.

62. da Cunha L, Sreerekha MV, Mackey D: Defense suppression by virulence effectors of bacterial phytopathogens. Curr Opin Plant Biol 2007, I0(4):349-357.
63. Axtell MJ, Chisholm ST, Dahlbeck D, Staskawicz BJ: Genetic and molecular evidence that the Pseudomonas syringae type III effector protein AvrRpt2 is a cysteine protease. Mol Microbiol 2003, 49(6): I537-I546.

64. Shao F, Golstein C, Ade J, Stoutemyer M, Dixon JE, Innes RW: Cleavage of Arabidopsis PBSI by a bacterial type III effector. Science 2003, 30 I(5637): | 230-I233.

65. Orbach MJ, Farrall L, Sweigard JA, Chumley FG, Valent B: A telomeric avirulence gene determines efficacy for the rice blast resistance gene Pi-ta. Plant Cell 2000, I 2(I I):2019-2032.

66. Rooney HC, Van't Klooster JW, Hoorn RA van der, Joosten MH, Jones JD, de Wit PJ: Cladosporium Avr2 inhibits tomato Rcr3 protease required for $\mathrm{Cf}$-2-dependent disease resistance. Science 2005, 308(5729): I783-1786.

67. Burg HA van den, Harrison SJ, Joosten MH, Vervoort J, de Wit PJ: Cladosporium fulvum Avr4 protects fungal cell walls against hydrolysis by plant chitinases accumulating during infection. Mol Plant Microbe Interact 2006, 19( I 2): | 420-। 430.

68. Rose JK, Ham KS, Darvill AG, Albersheim P: Molecular cloning and characterization of glucanase inhibitor proteins: coevolution of a counterdefense mechanism by plant pathogens. Plant Cell 2002, I 4(6): | 329-1345.

69. Tian M, Benedetti B, Kamoun S: A Second Kazal-like protease inhibitor from Phytophthora infestans inhibits and interacts with the apoplastic pathogenesis-related protease P69B of tomato. Plant Physiol 2005, I 38(3): I 785-I793.

70. Tian M, Huitema E, Da Cunha L, Torto-Alalibo T, Kamoun S: A Kazal-like extracellular serine protease inhibitor from Phytophthora infestans targets the tomato pathogenesis-related protease P69B. J Biol Chem 2004, 279(25):26370-26377.

71. DebRoy S, Thilmony R, Kwack YB, Nomura K, He SY: A family of conserved bacterial effectors inhibits salicylic acid-mediated basal immunity and promotes disease necrosis in plants. Proc Natl Acad Sci USA 2004, I OI(26):9927-9932.

72. Hauck P, Thilmony R, He SY: A Pseudomonas syringae type III effector suppresses cell wall-based extracellular defense in susceptible Arabidopsis plants. Proc Natl Acad Sci USA 2003, I 00( I4):8577-8582.

73. Boureau T, ElMaarouf-Bouteau H, Garnier A, Brisset MN, Perino C, Pucheu I, Barny MA: DspA/E, a type III effector essential for Erwinia amylovora pathogenicity and growth in planta, induces cell death in host apple and nonhost tobacco plants. Mol Plant Microbe Interact 2006, 19(I):16-24.

74. Sohn KH, Lei R, Nemri A, Jones JD: The downy mildew effector proteins ATRI and ATR I 3 promote disease susceptibility in Arabidopsis thaliana. Plant Cell 2007, I9( I 2):4077-4090.

75. He P, Chintamanani S, Chen Z, Zhu L, Kunkel BN, Alfano JR, Tang X Zhou JM: Activation of a COII-dependent pathway in Arabidopsis by Pseudomonas syringae type III effectors and coronatine. Plant J 2004, 37(4):589-602.

76. Brooks DM, Bender CL, Kunkel BN: The Pseudomonas syringae phytotoxin coronatine promotes virulence by overcoming salicylic-acid-dependent defences in Arabidopsis thaliana. Mol Plant Pathol 2005, 6:629-639.

77. Doyle EA, Lambert KN: Meloidogyne javanica chorismate mutase I alters plant cell development. Mol Plant Microbe Interact 2003, 16(2): |23-|3|.

78. Sijmons PC, Atkinson HJ, Wyss U: Parasitic strategies of root nematodes and associated host cell responses. Annu Rev Phytopathol 1994, 32:235-239.

79. Gohre V, Robatzek S: Breaking the barriers: microbial effector molecules subvert plant immunity. Annu Rev Phytopathol 2008, 46:189-215.

80. Semblat JP, Rosso MN, Hussey RS, Abad P, Castagnone-Sereno P. Molecular cloning of a cDNA encoding an amphid-secreted putative avirulence protein from the root-knot nematode Meloidogyne incognita. Mol Plant Microbe Interact 200I, I4(I):72-79.

81. Gleason CA, Liu QL, Williamson VM: Silencing a candidate nematode effector gene corresponding to the tomato resistance gene Mi-I leads to acquisition of virulence. Mol Plant Microbe Interact 2008, 21 (5):576-585.

82. Guide to GO Evidence Codes [http://www.geneontology.org/ GO.evidence.shtml] 